INTERNATIONAL JOURNAL OF MULTIDISCIPLINARY RESEARCH AND ANALySis

ISSN(print): 2643-9840, ISSN(online): 2643-9875

Volume 04 Issue 10 October 2021

DOI: 10.47191/ijmra/v4-i10-18, Impact Factor: 6.072

Page No.- $1449-1457$

\title{
Accessibility and use Behavior of Electronic Resources among Post Graduate Students of Bangalore University Library: A Study
}

\section{Amaravathi V}

Department of Library and Information Science, Bangalore University, JB Campus, Bangalore -56

ABSTRACT: This research paper examine the Accessibility and Use behavior of Electronic resources among Post Graduate students of Bangalore university library . there are 150 Questionnaire distributed to the Post graduate students of Bangalore university out of which $133(88.66 \%)$ filled questionnaires were received back from the students these are some objectives of the present study To know the Number of questionnaires distributed and received back To know course wise response received, To find out Gender wise response received, To know Age wise response received, To find out Knowledge on computer literacy, To know Frequency of visit to the library, To know purpose of visit to the library, To know Time spent in library, To find out Use of electronic resources, To know Frequency of use Electronic resources.

KEYWORDS: Accessibility, behavior, Electronic resources, university, questionnaires, gender, response, computer literacy, frequency.

\section{INTRODUCTION}

Electronic resources are playing very important role in this knowledge environmental era. E-resources are which is available in online and of line mode which are in electronic form such as e-books, e-journals, e-magazines, e-research reports, enewspapers, e-newsletters, e-databases, e-thesis and Dissertation, CD/DVD-Rom etc. university libraries are providing eresources to faculty members, students, Research scholars, teachers, and also for research purpose. electronic resources are comes under different formats including text, image, videos, audio, maps, graphics, tables, pictures etc.

\subsection{About Bangalore university :}

Bangalore University is located in the Garden City of Bangalore it was established in July 1964 as an off shoot of the University of Mysore, the University introduced Honours Courses in the year 1965-66. Three year Honour's courses in Botany, Chemistry, Economics, English, Geology, Kannada, Mathematics and Zoology which were offered only at the University Post Graduate Departments have attracted many brilliant students. Honours passed students were admitted to Post Graduate Courses on priority and B.A./B.Sc. graduates. Since 1964, Bangalore University has grown both in size and strength to include a large number of affiliated colleges, P.G. Centers with a rich diversity of programme options. In consonance with this expansion, in 1973, the University moved into a new campus named 'Jnana Bharathi' (JB) located on a sprawling 1100 acres of land and shifted many of its post graduate departments to this newly established campus

\section{LITERATURE REVIEW}

Kwafoa and others (2019) They examine in their research paper Survey methodology was adopted for this study, the findings revealed that awareness was high 138 (34.5\%) were aware of OPAC, 149 (37.3\%) were aware of Academic Databases whilst 93 (23.2\%) were aware of Dspace. 78 (19.5\%) of the respondents got to know of them from notices on campus, 63 (15.8\%) through flyers, $67(16.7 \%)$ through radio adverts, 26 (6.5\%) through newsletters, $43(10.8 \%)$ through posters and 123 or $30.7 \%$ through UCC library guide.266 (66.5\%) said the library had provided training on the use of OPAC while 134 (33.5\%) said the library had not provided training on use of OPAC. Also, 292 (73.0\%) said the library had provided training on the use of Academic databases while $108(27.0 \%)$ said the library had not provided training on using academic databases. Again, 273 (68.3\%) said the library had provided training on the use of Dspace. Anhwere and Paulina (2018) examine in their research paper the Survey method adopted for the study majority of the respondents that is 205 (51.2\%) access electronic resources both on and off campus, and only 138 (34.5\%) access their electronic resources on campus. Again, only 57 (14.3\%) access theirs off campus. $68 \%$ 


\section{Accessibility and use Behavior of Electronic Resources among Post Graduate Students of Bangalore University Library: A Study}

or 275 respondents indicated electronic resources access on campus as good compare to 30 (9.6\%) who indicated access off campus as good. $351(87.8 \%)$ of the respondents indicated useful in the use of academic database whilst $49(12.2 \%)$ indicated otherwise. Also, 269 (67.2\%) stated the usefulness of Dspace as compared to 131 (32.8\%) who stated otherwise. Again, 150 (37.5\%) of the respondents agreed that the OPAC is useful whilst the majority 250 (62.5\%) of the respondents disagreed. Kashyap (2017) This Study based on Survey Method. The finding reveal that Majority of P.G, students use e- resource for study purpose and least numbers of students use e- resource for seminar presentation. $70.64 \%$ Students are satisfied with Use of eresources. $16.91 \%$ very satisfied, $5.97 \%$ dissatisfied and $6.46 \%$ are unsure about satisfaction level. also found that majority (34.23\%) of the P.G. students spends $1-2$ hours in a week and least number of the Students (5.97\%) spends $4-5$ hours in week for e- resources.

\section{OBJECTIVES OF THE STUDY}

$>$ To know the Number of questionnaires distributed and received back

$>$ To know course wise response received

$>$ To find out Gender wise response received

$>$ To know Age wise response received

$>$ To find out Knowledge on computer literacy

$>$ To know Frequency of visit to the library

$>$ To know purpose of visit to the library

$>$ To know Time spent in library

$>$ To find out Use of electronic resources

$>$ To know Frequency of use Electronic resources

$>$ To find out Awareness of electronic resources

$>$ To know benefits of using e-resources

$>$ To find out separate section for accessing e-resources

$>$ To know overall Satisfaction of electronic resources

\section{SCOPE AND LIMITATIONS AND METHOD OF THE STUDY}

The present study limited only PG students of Bangalore university Library, Bangalore. The Survey method adopted for study there are 150 questionnaires distributed and 133(88.66\%) filled questionnaires were received back from the students.

\section{DATA ANALYSIS}

The collected data was analyzed and presented with tables and graphs

Table 1. Number of questionnaires distributed and received back

\begin{tabular}{|l|l|l|}
\hline No .of Questionnaires distributed & N. of questionnaires received back & $\%$ \\
\hline 150 & 133 & 88.66 \\
\hline
\end{tabular}

T 1 shows that Number of questionnaires distributed and received back from Post Graduate students of Bangalore University. There are 150 Questionnaire were distributed and 133(88.66\%) are received back.

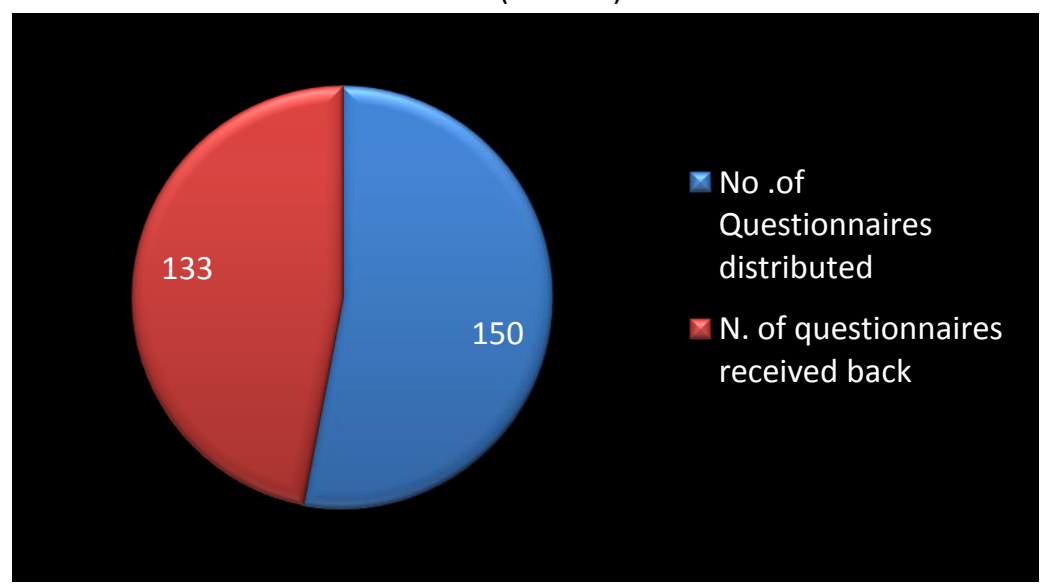

Fig. 1 Number of questionnaires distributed and received back 
Accessibility and use Behavior of Electronic Resources among Post Graduate Students of Bangalore University Library: A Study

Table 2. course wise response received

\begin{tabular}{|l|l|l|l|}
\hline Sl. No & Course & No. of respondents & $\%$ \\
\hline 1 & MA & 49 & 36.84 \\
\hline 2 & MSc & 46 & 34.58 \\
\hline 3 & Mcom & 38 & 28.58 \\
\hline Total & & 133 & 100 \\
\hline
\end{tabular}

T 2 shows that course wise response received from the students. There are $49(36.84 \%)$ studying MA followed by $46(34.58 \%)$ are MSc and $38(28.58 \%)$ are studying Mcom .

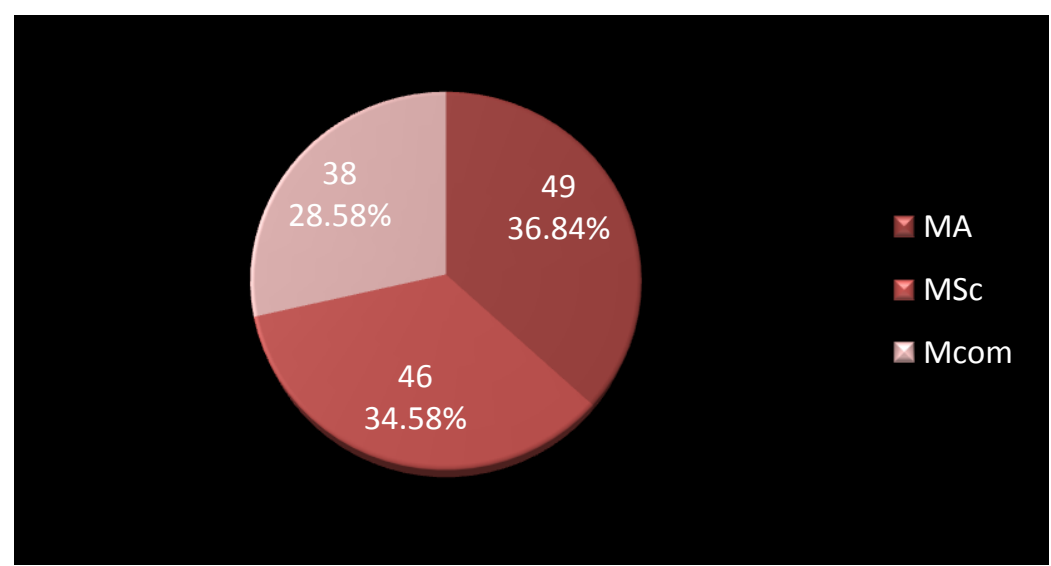

Fig.2 course wise response received.

Table 3. Gender wise response received

\begin{tabular}{|l|l|l|l|}
\hline Sl. No & Gender & No. of respondents & $\%$ \\
\hline 1 & Male & 60 & 45.11 \\
\hline 2 & Female & 73 & 54.89 \\
\hline Total & 133 & 100 \\
\hline
\end{tabular}

T3 shows that Gender wise response received from the students there are $60(45.11 \%)$ are male students and $73(54.89 \%)$ are Female.

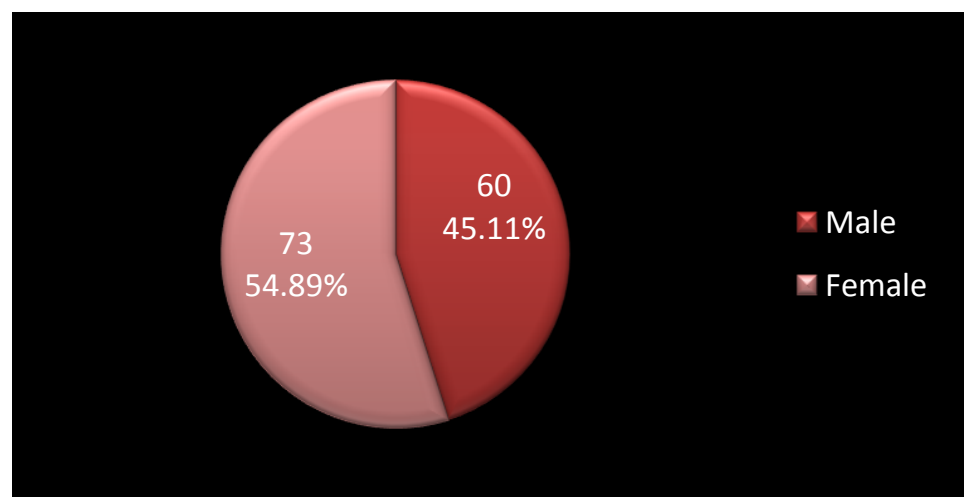

Fig.3 Gender wise response received.

Table 4. Age wise response received

\begin{tabular}{|l|l|l|l|}
\hline SI. No & Age & No. of respondents & $\%$ \\
\hline 1 & $21-23$ & 43 & 32.33 \\
\hline 2 & $24-26$ & 35 & 26.31 \\
\hline 3 & $27-30$ & 33 & 24.81 \\
\hline 4 & 31 and above & 22 & 16.55 \\
\hline Total & & 133 & 100 \\
\hline
\end{tabular}


Accessibility and use Behavior of Electronic Resources among Post Graduate Students of Bangalore University Library: A Study

T4 shows that Age wise response received there are 43(32.33\%) are between the age group of 21-23 years followed by $35(26.31 \%)$ are between the age group of $24-26,33(24.81 \%)$ are between the age group of $27-30$ Years and $22(16.55 \%)$ are between the age group of 31 and above.

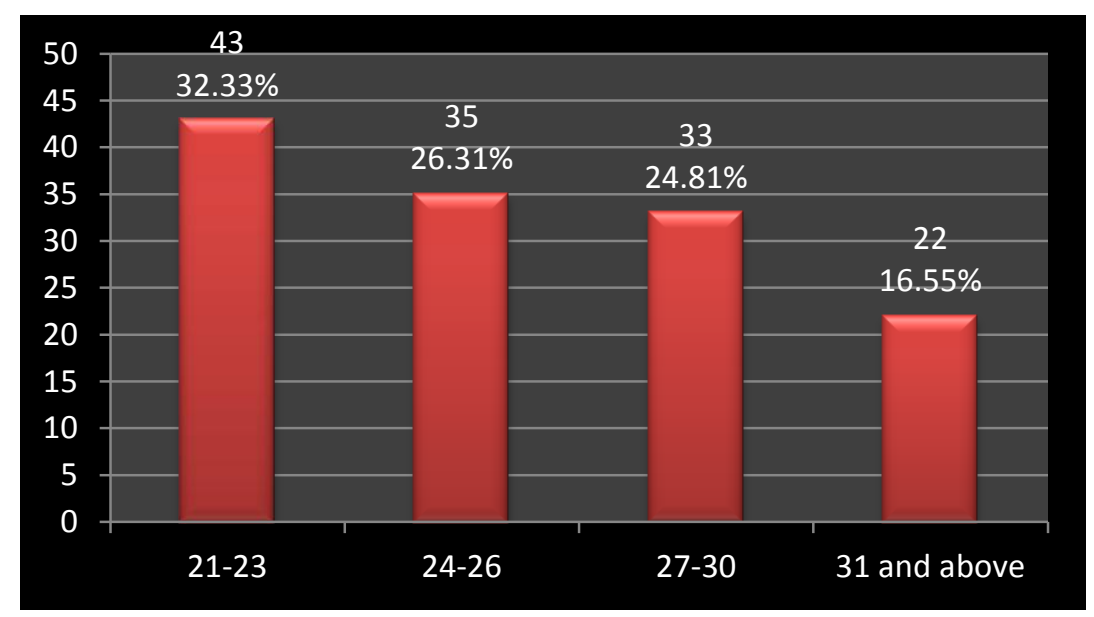

Fig.4 Age wise response received

Table 5. Knowledge on computer literacy

\begin{tabular}{|l|l|l|l|}
\hline Sl. No & Computer literacy & No. of respondents & $\%$ \\
\hline 1 & Yes & 133 & 100 \\
\hline 2 & No & Nil & 000 \\
\hline Total & 133 & 100 \\
\hline
\end{tabular}

T5 shows that Knowledge on computer literacy there are 133(100\%) are having knowledge on use of computers.

Table 6. Frequency of visit to the library

\begin{tabular}{|l|l|l|l|}
\hline Sl. No & Frequency & No. of respondents & $\%$ \\
\hline 1 & Every Day & 44 & 33.08 \\
\hline 2 & Once in a week & 26 & 19.55 \\
\hline 3 & Two times in a week & 25 & 18.79 \\
\hline 4 & Once in a month & 19 & 14.29 \\
\hline 5 & Rarely & 19 & 14.29 \\
\hline Total & 133 & 100 \\
\hline
\end{tabular}

T6 Shows that Frequency of visit to the library there are 44(33.08\%) were visit library Every Day followed by $26(19.55 \%)$ were visit library Once in a week, 25(18.79\%) were visit their library Two times in a week, 19(14.29\%) were visit library Once in a month and 19(14.29\%) were visit library Rarely.

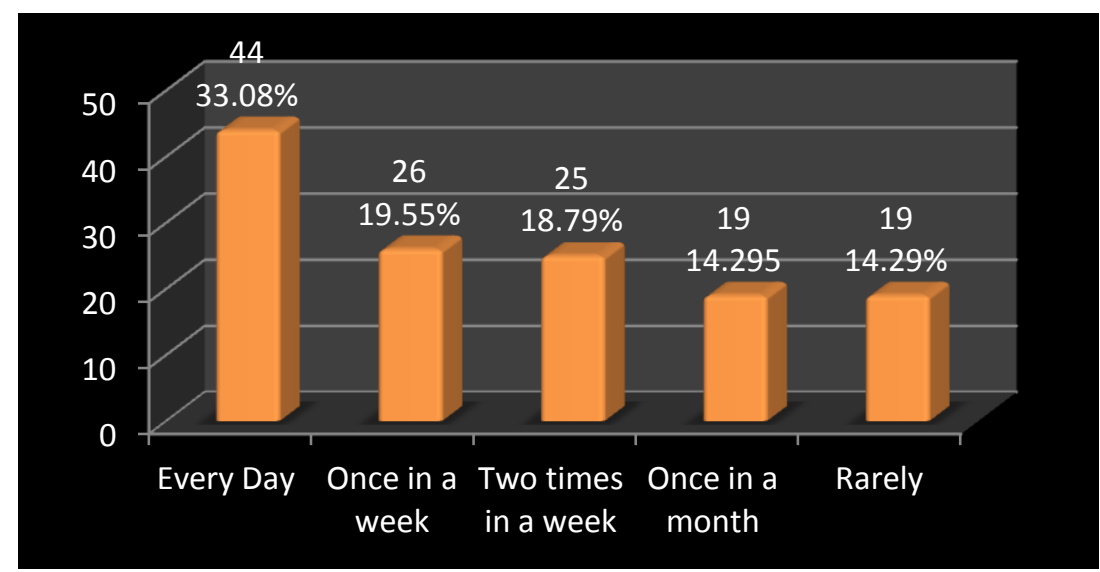

Fig. 5 Frequency of visit to the library 
Accessibility and use Behavior of Electronic Resources among Post Graduate Students of Bangalore University Library: A Study

Table 7. Purpose of visit to the library

\begin{tabular}{|l|l|l|l|}
\hline Sl. No & purpose & No. of respondents & $\%$ \\
\hline 1 & To issue/return of the books & 47 & 35.33 \\
\hline 2 & To access internet & 23 & 17.29 \\
\hline 3 & To complete assignment & 19 & 14.29 \\
\hline 4 & For research work & 13 & 09.78 \\
\hline 5 & To use e-resources & 14 & 10.53 \\
\hline 6 & For Xerox/print out & 17 & 12.78 \\
\hline Total & & 133 & 100 \\
\hline
\end{tabular}

T7 Shows that purpose of visit to the library there are 47(35.33\%) were visit library for the purpose To issue/return of the books followed by $23(17.29 \%)$ were visit library for the purpose of To access internet, $19(14.29 \%)$ were visit library To complete assignment, 13(09.78\%) were visit library For research work, 14(10.53\%) were visit library To use e-resources and 17(12.78\%) were visit library For Xerox/print out only.

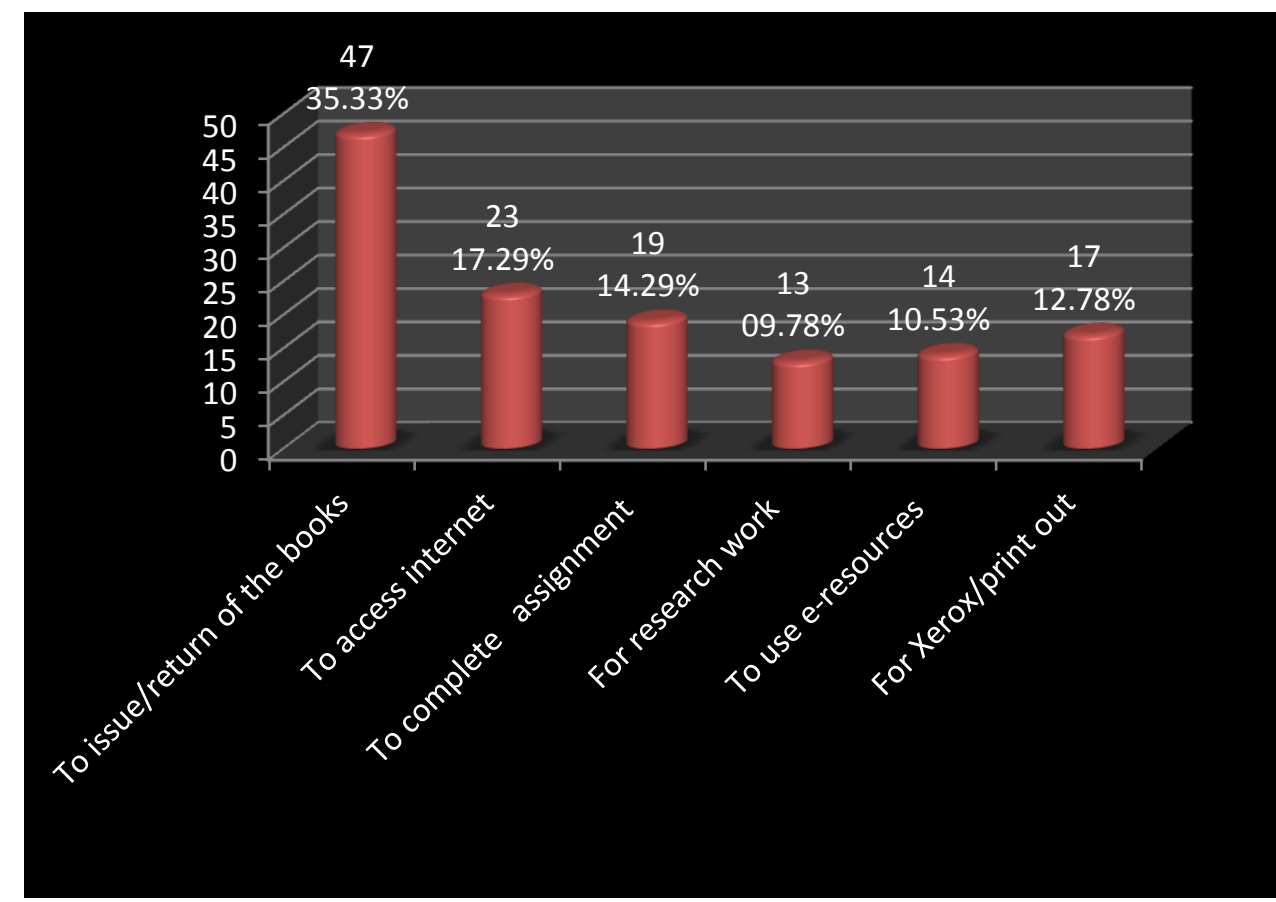

Fig.6 purpose of visit to the library

Table 8. Time spent in library

\begin{tabular}{|l|l|l|l|}
\hline $\begin{array}{l}\text { Sl. } \\
\text { No }\end{array}$ & Time & $\begin{array}{l}\text { No. } \\
\text { respondents }\end{array}$ & $\%$ \\
\hline 1 & 1 to 2 hours & 39 & 29.33 \\
\hline 2 & 2 to 3 hours & 35 & 26.32 \\
\hline 3 & 3 to 4 hours & 31 & 23.30 \\
\hline 4 & 4 hours and above & 28 & 21.05 \\
\hline Total & 133 & 100 \\
\hline
\end{tabular}

T8 shows that Time spent in library there are 39(29.33\%) were Spent 1 to 2 hours time in library followed by 35(26.32\%) were spent 2-3 hours time, 31(23.30\%) were spent 3-4 hours time, $28(21.05 \%)$ were spent 4 hours and above in library. 
Accessibility and use Behavior of Electronic Resources among Post Graduate Students of Bangalore University Library: A Study

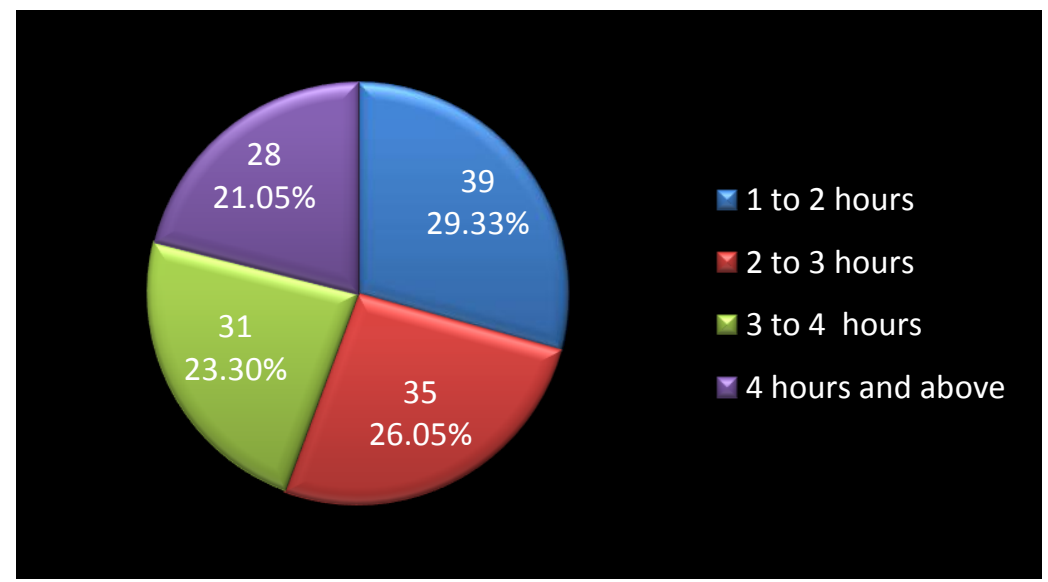

Fig.7 Time spent in library

Table 9. Use of electronic resources

\begin{tabular}{|l|l|l|l|}
\hline SI. No & Use of e-resources & No. of respondents & $\%$ \\
\hline 1 & Yes & 133 & 100 \\
\hline 2 & No & Nil & 000 \\
\hline Total & 133 & 100 \\
\hline
\end{tabular}

T 9 shows that Use of electronic resources there are 133(100\%) were using electronic resources in their library.

Table 10. Frequency of use Electronic resources

\begin{tabular}{|l|l|l|l|}
\hline SI. No & Frequency & No. of respondents & $\%$ \\
\hline 1 & Daily & 41 & 30.83 \\
\hline 2 & Once in a week & 37 & 27.81 \\
\hline 3 & Two times in a week & 31 & 23.30 \\
\hline 4 & Three times in a week & 11 & 08.28 \\
\hline 5 & Once in a month & 13 & 09.78 \\
\hline Total & 133 & 100 \\
\hline
\end{tabular}

T 10 Shows that Frequency of use Electronic resources there are 41(30.83\%) were Daily visit library to use Electronic resources followed by $37(27.81 \%)$ visit library Once in a week, $31(23.30 \%)$ were visit library Two times in a week, $11(08.28 \%)$ were visit library Three times in a week, 13(09.78\%) were visit library Once in a month.

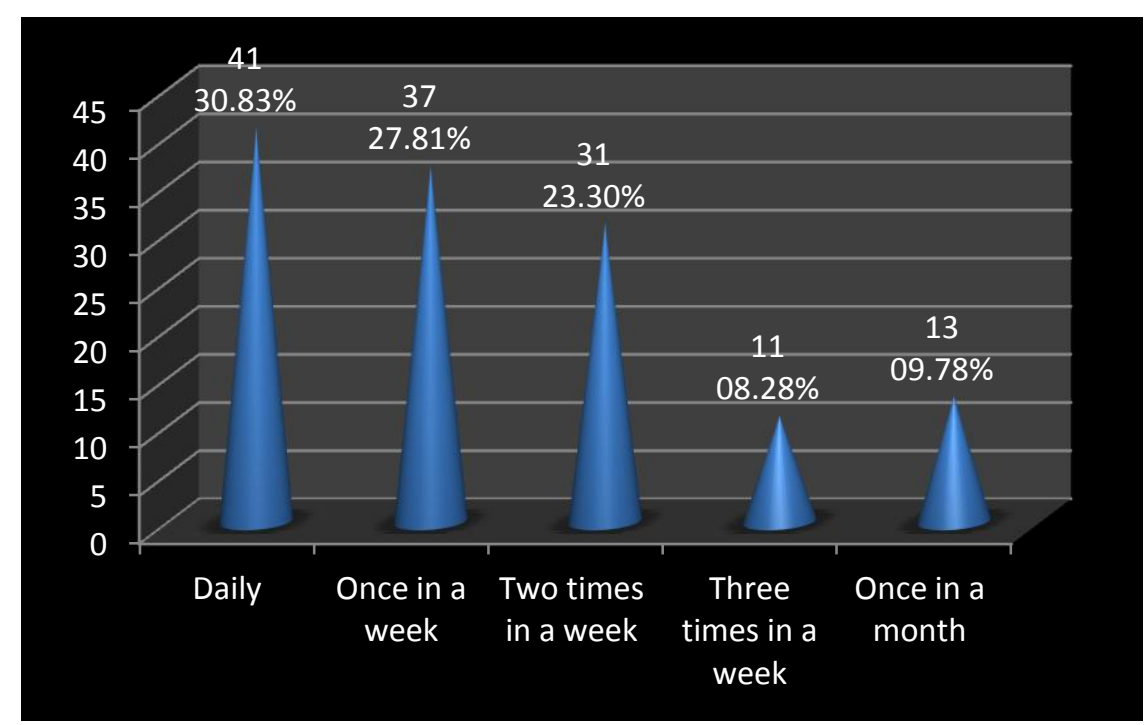

Fig.8 Frequency of use Electronic resources 
Accessibility and use Behavior of Electronic Resources among Post Graduate Students of Bangalore University Library: A Study

Table 11. Awareness of electronic resources (Responded more than one option)

\begin{tabular}{|l|l|l|l|}
\hline SI. No & e- resources & No. of respondents & $\%$ \\
\hline 1 & e-Books & 120 & 90.22 \\
\hline 2 & e-journals & 110 & 82.70 \\
\hline 3 & e-theses/ e-dissertations & 121 & 90.97 \\
\hline 4 & e-Newspapers & 133 & 100 \\
\hline 5 & CD ROMs/DVDs & 133 & 100 \\
\hline 6 & Search engines & 115 & 86.46 \\
\hline
\end{tabular}

T11 shows that Awareness of electronic resources. There are 120(90.22\%) were aware of Electronic Books followed by 110(82.70\%) were aware of Electronic Journals 121 (90.97\%) were aware of e-theses/ e-dissertations, 133(100\%) were of eNewspapers, 133(100\%) were aware of CD ROMs/DVDs and 115(86.46\%) were aware of Search engines.

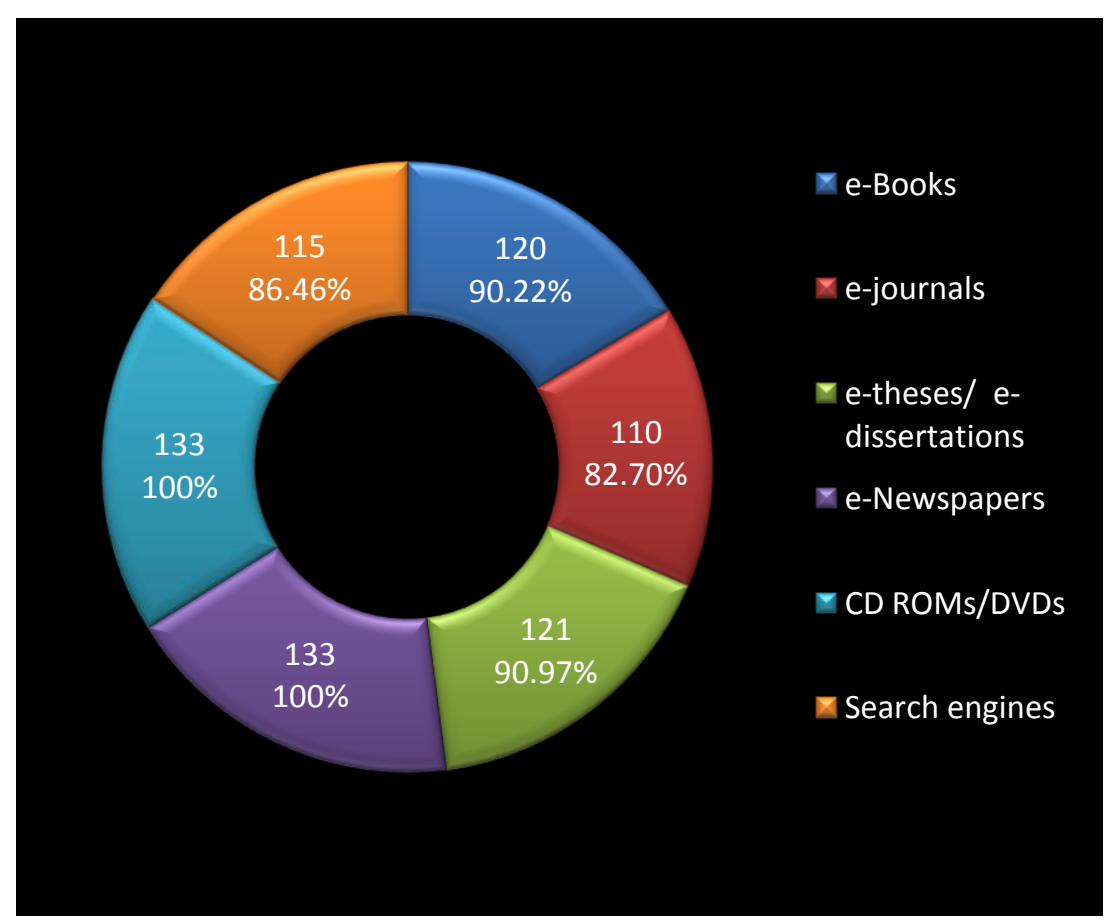

Fig.9 Awareness of electronic resources

Table 12. Benefits of using e-resources (Responded more than one option)

\begin{tabular}{|l|l|l|l|}
\hline $\begin{array}{l}\text { Sl. } \\
\text { No }\end{array}$ & Benefits & $\begin{array}{l}\text { No. of } \\
\text { respondents }\end{array}$ & $\%$ \\
\hline 1 & Up to date knowledge & 098 & 73.68 \\
\hline 2 & Faster information access & 110 & 82.70 \\
\hline 3 & Access other e-resources & 89 & 66.91 \\
\hline 4 & Save the time & 130 & 97.74 \\
\hline 5 & Easy to read & 127 & 95.48 \\
\hline
\end{tabular}

T12 shows that benefits of using e-resources there are 98(73.68\%) were using for Up to date knowledge followed by 110(82.70\%) were using for Faster information access, 89(66.91\%) were Access other e-resources, 130 (97.74\%) were Save the time and $127(95.48 \%)$ were using electronic resources to Easy to read. 
Accessibility and use Behavior of Electronic Resources among Post Graduate Students of Bangalore University Library: A Study

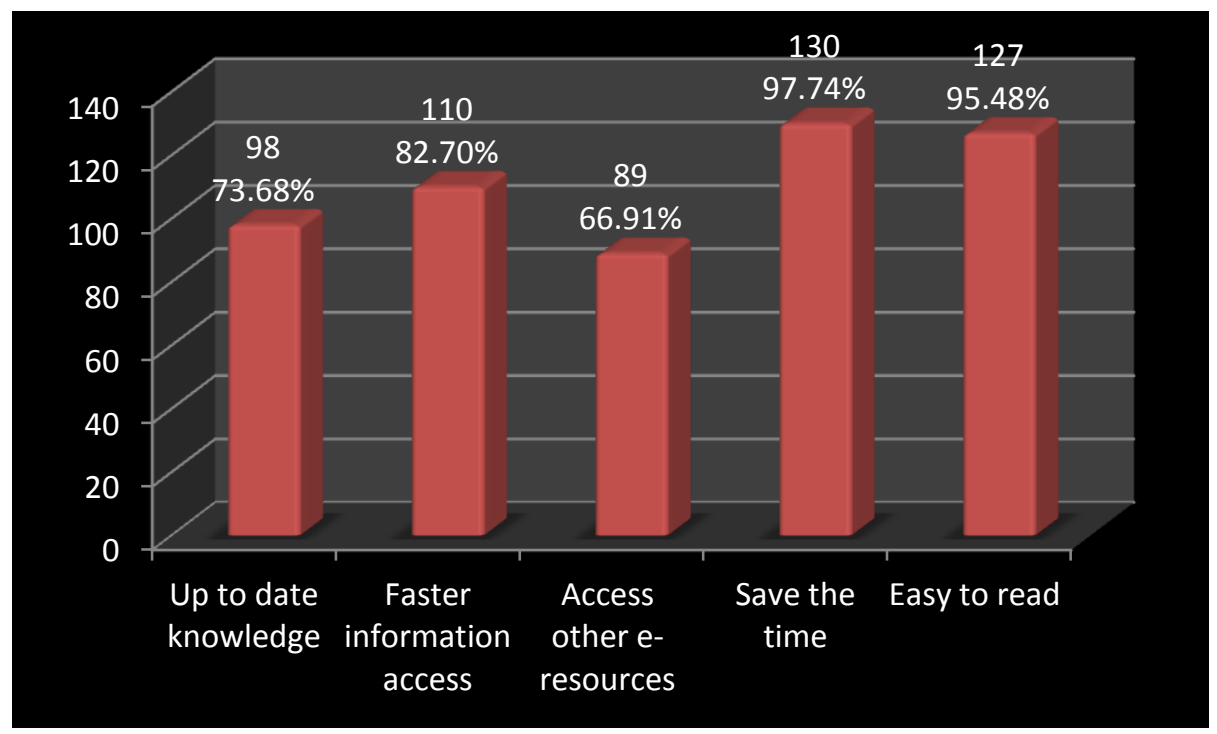

Fig.10 benefits of using e-resources

Table 13. separate section for accessing e-resources

\begin{tabular}{|l|l|l|l|}
\hline SI. No & Separate Section & No. of respondents & $\%$ \\
\hline 1 & Yes & 133 & 100 \\
\hline 2 & No & Nil & 000 \\
\hline Total & 133 & 100 \\
\hline
\end{tabular}

T 13 Shows that separate section for accessing e-resources there are 133(100\%) were responded that they are having separate section for accessing e-resources.

Table 14. Overall Satisfaction of electronic resources

\begin{tabular}{|l|l|l|l|}
\hline SI. No & Satisfaction & No. of respondents & $\%$ \\
\hline 1 & satisfied & 83 & 62.40 \\
\hline 2 & Partially satisfied & 43 & 32.33 \\
\hline 3 & Not satisfied & 07 & 05.27 \\
\hline Total & 133 & 100 \\
\hline
\end{tabular}

T14 shows that overall Satisfaction of electronic resources there are $83(62.40 \% 0$ were Satisfied with e-resources followed by 43(32.33\%) were Partially satisfied and 07(05.27\%) were Not satisfied.

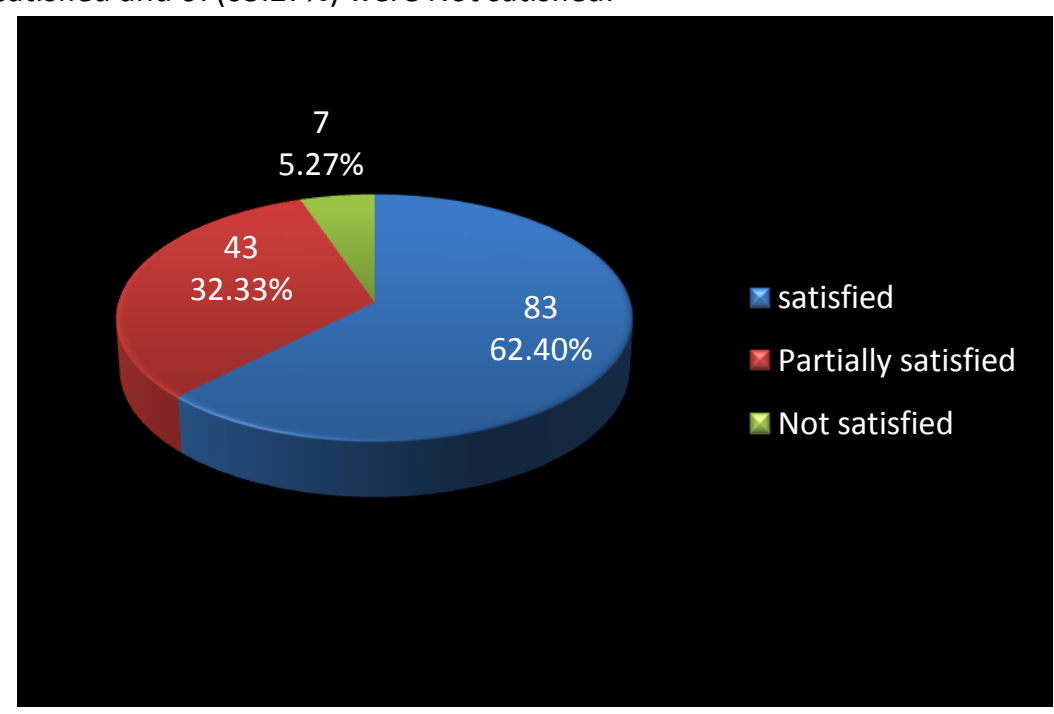

Fig.11 overall Satisfaction of electronic resources 


\section{Accessibility and use Behavior of Electronic Resources among Post Graduate Students of Bangalore University Library: A Study}

\section{FINDINGS AND CONCLUSION OF PRESENT STUDY}

The major findings of the study revealed that There are 150 Questionnaire were distributed and $133(88.66 \%)$ are received back from the students followed by $49(36.84 \%)$ studying MA, 46(34.58\%) are MSc and 38(28.58\%) are studying Mcom, 60(45.11\%) are male students and $73(54.89 \%)$ are Female, $43(32.33 \%)$ are between the age group of $21-23$ years $35(26.31 \%)$ are between the age group of $24-26,33(24.81 \%)$ are between the age group of $27-30$ Years and $22(16.55 \%)$ are between the age group of 31 and above, 44(33.08\%) were visit library Every Day, 26(19.55\%) were visit library Once in a week, 25(18.79\%) were visit their library Two times in a week, 19(14.29\%) were visit library Once in a month and 19(14.29\%) were visit library Rarely, 47(35.33\%) were visit library for the purpose To issue/return of the books 23(17.29\%) were visit library for the purpose of To access internet,19(14.29\%) were visit library To complete assignment,13(09.78\%) were visit library For research work, 14(10.53\%) were visit library To use e-resources and 17(12.78\%) were visit library For Xerox/print out only, 39(29.33\%) were Spent 1 to 2 hours time in library, 35(26.32\%) were spent 2-3 hours time, 31(23.30\%) were spent 3-4 hours time, $28(21.05 \%)$ were spent 4 hours and above in library.

\section{REFERENCES}

1) Anhwere,Barfi Kwaku and Afful-Arthur Paulina (2018) Accessibility and Postgraduate Students Use of Electronic Resources in University of Cape Coast, Research Journal of Library and Information Science, 2(1), 9-14.

2) Jogan, Sushma N (2015) Access, Awareness And Use Of Electronic Resources By Post Graduate Students In Gulbarga University, International Journal of Informative \& Futuristic Research.2(6).

3) Kashyap, Santu Ram (2017) A Study On Use Of E- Resources By Post Graduate Students Of Govt. Nagarjun P.G. Science College Raipur, Chhattisgarh, International Journal of Digital Library Services, 7(2).

4) Kwafoa, Paulina Nana Yaa, Anhwere, Barfi Kwaku and Manu Agyapong Emmanuel (2019) Use of electronic resources by postgraduate students in University of Cape Coast, International Journal of Library and Information Science, 11(2), 7-13.

5) Naik, K.G. Jayarama (2020) Use of Library Resources and Services by the PG Students: A Case Study of Bangalore University Library, Bengaluru, International Journal of Research in Library Science (IJRLS), 6(2).

6) Okiki, Olatokunbo Christopher and Asiru, S. M.(2011) "Use of Electronic Information Sources by Postgraduate Students in Nigeria: Influencing Factors". Library Philosophy and Practice (e-journal).500. https://digitalcommons.unl.edu/libphilprac/500

7) Ozoemelem, Obuh Alex (2009)"Use of Electronic Resources by Postgraduate Students of the Department of Library and Information Science of Delta State University, Abraka, Nigeria". Library Philosophy and Practice (e-journal). 301.

8) Sonkar, Sharad Kumar, Singh M.P and Kumar Jitendra (2014) Use of Electronic Resources by Post Graduate Students and Research Scholars of the Banaras Hindu University: A Study, Journal of Information Management, 1(2), 87-97. 